\title{
Kinetic and thermodynamic adsorption of nickel (II) onto hydroxyapatite prepared from Snakehead (Channa striata) fish bone
}

\author{
Poedji Loekitowati Hariani * Muryati and Muhammad Said \\ Department of Chemistry, Faculty of Mathematics and Natural Sciences, Sriwijaya University, Ogan Ilir 30662, \\ Indonesia
}

\begin{abstract}
Biomaterial exploration base on solid waste has been an attractive issue, particularly regarding economic and environmental demand. This work aimed to extract hydroxyapatite from snakehead fishbone through precipitation method and used to remove Ni(II). The hydroxyapatite product was characterized by using X-ray Diffraction (XRD), Fourier Transform Infrared spectroscopy (FTIR), Scanning Electron MicroscopeEnergy Dispersive Spectroscopy (SEM-EDS) and Brunauer Emmett Teller (BET) method. Batch adsorption experiment includes $\mathrm{pH}$ solution, contact time and $\mathrm{Ni}$ (II) concentration. Pseudo-first order and pseudo-secondorder were used to investigate the reaction mechanism and kinetic model, while adsorption equilibrium was evaluated according to Langmuir and Freundlich isotherm. XRD and FTIR spectra confirmed that hydroxyapatite was successfully extracted. The molar ratio $(\mathrm{Ca} / \mathrm{P})$ of hydroxyapatite was found at 1.70 . The particle size of the hydroxyapatite was $48.77 \mathrm{~nm}$. The pseudo-second-order is appropriate to describe the kinetic model while the adsorption mechanism follows Langmuir isotherm, which has an adsorption capacity of $5.359 \mathrm{mg} / \mathrm{g}$. The thermodynamic evaluation suggested the adsorption of $\mathrm{Ni}(\mathrm{II})$ is spontaneous in the endothermic process.
\end{abstract}

Keywords: snakehead fish bone, hydroxyapatite, adsorption, $\mathrm{Ni}(\mathrm{II})$

\section{Introduction}

Advanced industrial activity creates massive ecosystem damage in the form of a harmful pollutant for both human and environment. One of the related issues that have been reported by many authors is heavy metal removal from liquid waste which pollutes the aquatic environment ${ }^{1}$. Heavy metal ions in low level such as nickel, lead, cadmium, copper etc... are non-biodegradable and hazardous ${ }^{2}$. Furthermore, heavy metal tends to bioaccumulate in the environment, which makes it more risk ${ }^{3}$. Nickel is classified as a heavy metal that used in much industrial application such as metal alloy, paint, printing, electroplating, plastic, battery, electric power and mining which can be released to the environment as $\mathrm{Ni}(\mathrm{II})^{4,5}$. Some anions correlated to $\mathrm{Ni}$ (II) such as sulfide, nitrate, chloride interact chemically to form salts that dissolved in water. Intake of $\mathrm{Ni}$ (II) into the human body caused several health problems, e.g. skin dermatitis, anaemia, indigestion, hepatitis, and lung and kidney damage $3,4,5$. Ni(II) accumulation in the long term creates a high concentration within the body which can lead to lung as well as nose and bone cancer ${ }^{3,6}$. According to the World Health Organization, the maximum of $\mathrm{Ni}$ in drinking water is $0.5 \mathrm{mg} / \mathrm{L}$. Therefore, it is essential

*Corresponding author: Poedji Loekitowati Hariani Email address: puji lukitowati@mipa.unsri.ac.id DOI: http://dx.doi.org/10.13171/mjc92190906825plh to reduce $\mathrm{Ni}$ (II) in aqueous so as not to pollute the environment.

A heavy metal pollutant can be removed by several methods, i.e. filtration, ion exchange, reductionoxidation, flocculation, chemical precipitation, membrane, and adsorption. Among these methods, adsorption is acclaimed as the most straightforward, low cost and effective way to remove pollutants ${ }^{7,8}$. The adsorbent can be sourced from various organic and inorganic materials. Attention has been grown on using low-cost natural-based adsorbent. Several authors had been reported using biomaterial in $\mathrm{Ni}$ (II) adsorption such as physic seed hull ${ }^{2}$, calotropis procera ${ }^{3}$, mustard oil cake ${ }^{5}$, activated carbon from coir pith ${ }^{6}$, bovine bond ${ }^{9}$, moringa oleifera bark ${ }^{10}$, and pseudomonas oleovorans ${ }^{11}$.

Hydroxyapatite is a biomaterial that has structure and composition similar to natural bone ${ }^{12}$. It is highly biocompatible with skin and dental gums so that it can use as bone and dental implant ${ }^{13}$. Hydroxyapatite can also be used as a catalyst, ion exchange, and adsorbent 14,15 . The molecular structure of this material is $\mathrm{Ca}_{10}\left(\mathrm{PO}_{4}\right)_{6}(\mathrm{OH})_{2}$ which resembles an apatite compound. Several authors used hydroxyapatite for pollutant removal due to high affinity, low solubility, high stability, and economical 1,16,17. Among waste

Received July 12, 2019

Accepted August 1, 2019

Published September 6, 2019 
and pollutants reported being removed by hydroxyapatite were zinc ${ }^{1}$, reactive blue ${ }^{8}$, copper ${ }^{16}$, strontium ${ }^{18}$, oxytetracycline ${ }^{19}$, and lead ${ }^{20}$. The mechanism of heavy metal ion adsorption by hydroxyapatite involve $\mathrm{Ca}$ cation exchange within its structure 16,21 . In addition to cation adsorption, hydroxyapatite was also reported for anion adsorption such as fluoride ${ }^{22}$.

There are a variety of sources can be used to synthesize hydroxyapatite. Calcium contains biomaterial, as well as biowaste, can be used for this purpose such as swordfish and tuna ${ }^{12}$, eggshell ${ }^{15}$, Roho labio fish bone ${ }^{23}$, oyster shell ${ }^{24}$ and pensi shell 25. Using biowaste for hydroxyapatite synthesis provide some advantages i.e. low cost, available in abundant amount and also environmentally friendly. Fishbone shows great potential for the production of hydroxyapatite because millions of tons of fish were captured and consumed worldwide annually ${ }^{26}$. Consumption of fish provides solid wastes estimate of $30-40 \%$ ie bone, scale, skin ${ }^{21}$. Such a vast number of wastes undoubtedly caused serious environment problem as well as health disorders. High calcium content within fish bone made this material a good precursor for hydroxyapatite synthesis.

Hydroxyapatite in this work was synthesized from snakehead (Channa striata) fish bone. Snakehead is a freshwater fish, the name of residents as Gabus fish. This fish has been cultivated for a long time ago. The method of hydroxyapatite preparation such as heat treatment ${ }^{23}$, co-precipitation ${ }^{24,27}$, sol-gel ${ }^{28}$, combustion ${ }^{29}$ and ultrasonic ${ }^{30}$. The choice of preparation method will affect hydroxyapatite crystallinity, the molar ratio of $\mathrm{Ca} / \mathrm{P}$, and particle size 31. Precipitation method is also classified as wet chemical precipitation has been widely used in hydroxyapatite synthesis because of its simplicity and high yield of product ${ }^{32}$. Generally, hydroxyapatite was synthesized in the form of the nanoparticle. The material in nanosize has a surface area, and high reactivity is more significant compared to bulk material ${ }^{33}$. Hydroxyapatite obtained in this work was characterized using XRD, FTIR, SEM-EDS and BET method. This material was tested in Ni(II) adsorption from aqueous solution.

\section{Experimental}

\subsection{Material}

Snakehead fish was acquired from the domestic market located in Palembang, South Sumatera, Indonesia. Chemicals were purchased from Merck (Germany) in analytical grade i.e. $\mathrm{HCl},\left(\mathrm{NH}_{4}\right)_{2} \mathrm{HPO}_{4}$, $\mathrm{NH}_{4} \mathrm{OH}, \mathrm{NiCl}_{2} \cdot 6 \mathrm{H}_{2} \mathrm{O}, \mathrm{NaOH}$. The solvent in the majority of procedures used double distilled water.

\subsection{Hydroxyapatite synthesis ${ }^{34}$}

Fishbone was cleaned of dirt and washed using distilled water and boiled for 90 minutes to remove the flesh. The fish bones were cut to obtain $5 \mathrm{~mm}$ in size followed by reflux method using $\mathrm{HCl} 4 \%$ for 30 minutes. After that, the fishbone was neutralized using distilled water. The bone heating in an oven at $100^{\circ} \mathrm{C}$ for 2 hours followed by calcination in a muffle furnace for 4 hours at $800{ }^{\circ} \mathrm{C}$ with a heating rate was set of $10^{\circ} \mathrm{C} / \mathrm{min}$. This process converts $\mathrm{CaCO}_{3}$ to $\mathrm{CaO}$. $\mathrm{CaO}$ product was crushed into nanosized by using high energy ball milling (Shaker mill PPF-UG) for 5 hours to obtain a powder. $2.8 \mathrm{~g}$ of powder $\mathrm{CaO}$ was added of $250 \mathrm{~mL}$ distilled water and boiled for one hour. $150 \mathrm{~mL}\left(\mathrm{NH}_{4}\right)_{2} \mathrm{HPO}_{4}(0.2 \mathrm{M})$ was added into the solution in an inert atmosphere by flowing $\mathrm{N}_{2}$. The mixture was heated at $100^{\circ} \mathrm{C}$ while $\mathrm{NH}_{4} \mathrm{OH} 1 \mathrm{M}$ was added dropwise until $\mathrm{pH}$ reaches 11 . Hydroxyapatite was collected by filtration and drying in the oven at $105^{\circ} \mathrm{C}$ for 2 hours.

\subsection{Characterization of hydroxyapatite}

Functional groups in hydroxyapatite were evaluated by using Fourier Transform Infrared (FTIR Thermo Scientific Nicolet iS10) and applying $\mathrm{KBr}$ pellet scanned at wavenumber range $4000-500 \mathrm{~nm}^{-1}$. The morphology was observed using Scanning Electron Microscope (SEM-EDS VEGA 3 TESCAN) equipped with EDS (Energy Dispersive X-ray Spectroscopy) to determine hydroxyapatite element content. The surface area of hydroxyapatite was measured by the BET method using $\mathrm{N}_{2}$ adsorptiondesorption (Nova 4200e).

The phase composition of the hydroxyapatite was characterized by using X-ray Diffraction (XRD Rigaku Miniflex 600) using $\mathrm{Cu} \mathrm{K} \alpha$ radiation $(\lambda=0.15406 \mathrm{~nm})$ at $2 \theta$ range $10-80^{\circ}$. The average particle size $(d)$ was determined by using the DebyeScherrer equation ${ }^{12,34}$ :

$d=\frac{k \lambda}{\beta \cos (\theta)}$

Where $\mathrm{k}$ is a constant associated with the crystal shape (0.9), $\beta$ is a full-width peak at half maximum intensity $(\mathrm{rad}), \lambda$ is X-Ray radiation wavelength $(1.5418 \AA)$. Data used to calculate particle size was based on line broadening at reflection plane (211), assuming that it provides excellent resolution and no interference occurred.

\subsection{Adsorption of $\mathrm{Ni}(\mathrm{II})$}

The adsorption of $\mathrm{Ni}$ (II) was conducted in the batch method. $\mathrm{pH}_{\text {PZC }}$ obtained by $50 \mathrm{mg}$ of adsorbent was put into $50 \mathrm{~mL}$ of $0.5 \mathrm{M} \mathrm{KCl}, \mathrm{pH}$ of the solution made from 3 to 10 with addition $\mathrm{HCl}$ and $\mathrm{NaOH} 0.01 \mathrm{M}$. After 24 hours, obtained the $\mathrm{pH}$ of the solution. The optimum condition for adsorption was evaluated by varying the solution $\mathrm{pH}$, contact time and initial concentration of $\mathrm{Ni}(\mathrm{II})$. Determination of optimum $\mathrm{pH}$ was conducted by $0.1 \mathrm{~g}$ of hydroxyapatite was dispersed in $50 \mathrm{~mL} \mathrm{Ni(II)} \mathrm{solution} \mathrm{with} \mathrm{a}$ concentration of $30 \mathrm{mg} / \mathrm{L}$. The mixture was stirred at $150 \mathrm{rpm}$ and a temperature of $25^{\circ} \mathrm{C}$ for 100 minutes. Solution $\mathrm{pH}$ was varied in range $3-10$ by adding $\mathrm{HCl}$ and $\mathrm{NaOH}$. After adsorption, the solution determined of $\mathrm{Ni}$ (II) concentration which is not absorbed by 
Atomic Absorption Spectroscopy (AA-7000 Shimadzu). Contact time for adsorption was evaluated by using a similar procedure with time as variable i.e. 10 to 120 minutes. The initial concentration of $\mathrm{Ni}(\mathrm{II})$ was set at a different amount ranged from 10 to $30 \mathrm{mg} / \mathrm{L}$. The experiment was carried out triplicate.

\section{Results and Discussion}

\subsection{Characterization of hydroxyapatite}

The crystal structure of fishbones and hydroxyapatite was evaluated using XRD, as shown in Figure 1. The amorphous structure of fishbone can be seen as a wide peak on the diffractogram obtained. Also,

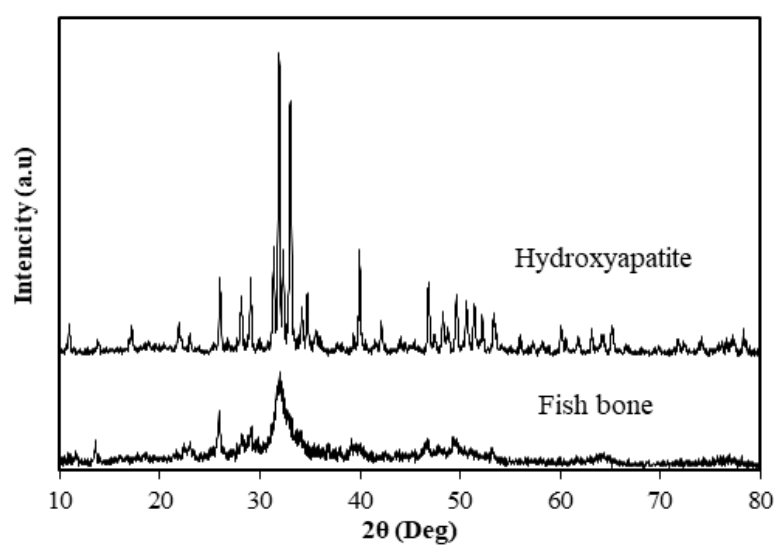

Figure 1. X-ray diffractogram of hydroxyapatite hydroxyapatite appears at a sharp peak higher than fish bone. According to JCPDS 09-0432, hydroxyapatite has hexagonal crystal showing peaks at $2 \theta=25.879 ; 31.773 ; 32.196 ; 32.902 ; 46.711$; 49.468; 50.493 and $53.143^{\circ}$ which correspond with reflection plane $002,211,112,300,202,310,222$, 213,321 and $004^{7}$. Diffractogram of hydroxyapatite in this work shows peaks at $2 \theta=25.98 ; 31.92 ; 32.98$; $33.03 ; 46.80 ; 49.58 ; 50.56$ and $53.26^{\circ}$. The particle size of hydroxyapatite calculated by using DebyeScherrer is $\pm 48.77 \mathrm{~nm}$. Based on this result, the material obtained is nanoparticle $(<100 \mathrm{~nm})$ or nanohydroxyapatite ${ }^{35}$.

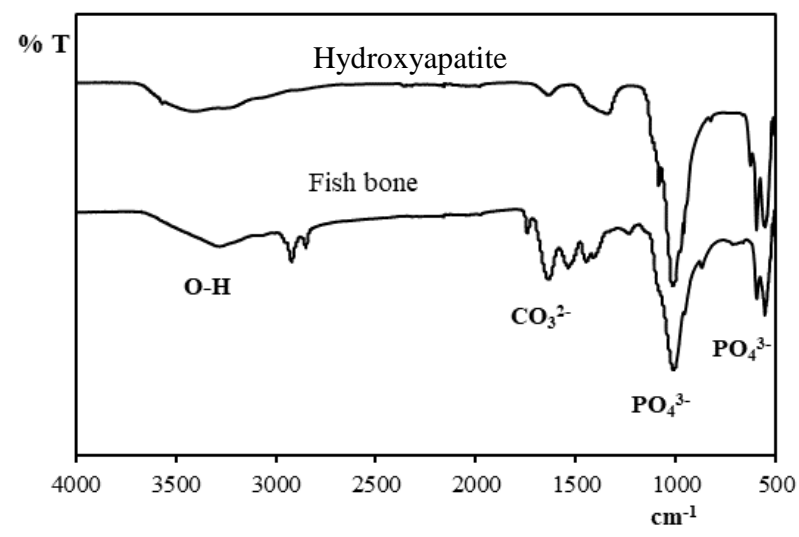

Figure 2. FTIR spectra of hydroxyapatite

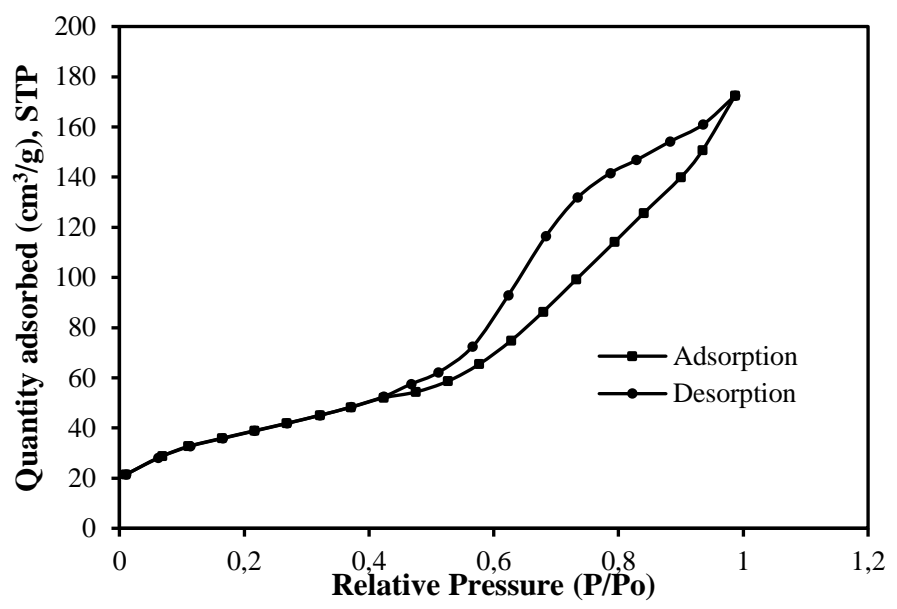

Figure 3. $\mathrm{N}_{2}$ adsorption-desorption isotherm of hydroxyapatite

Hydroxyapatite prepared from snakehead fish bone has FTIR spectra (Figure 2) similar to hydroxyapatite synthesized from bovine bone ${ }^{9}$ and Lates calcarifer fish bone ${ }^{36}$. The P-O group can be identified at the wavenumber of $500-1100 \mathrm{~cm}^{-1}$. The FTIR spectra of hydroxyapatite showed peaks at wavenumber 542 and $594 \mathrm{~cm}^{-1}$ that resemble vibration mode of the $\mathrm{P}-\mathrm{O}$ group while the vibration stretch for this bond appears at $993 \mathrm{~cm}^{-1}$. The sharp peak at $1010 \mathrm{~cm}^{-1}$ also assigned for P-O bond from $\mathrm{PO}_{4}{ }^{3-}$. Fishbone powder reveals similar peaks at a lower intensity. Therefore, the powder contains a phosphate group within its structure. High and sharp peaks belonging to fish bone powder appeared at wavenumber 1400 and $1420 \mathrm{~cm}^{-1}$ which indicate the existence of $\mathrm{C}-\mathrm{O}$ stretching from carbonate group $\left(\mathrm{CO}_{3}{ }^{2-}\right)$. Another possibility for this peak comes from $\mathrm{CO}_{2}$ adsorbed on hydroxyapatite surface ${ }^{37,38}$. Stretching vibration from O-H group at with wavenumber 3210 and $3530 \mathrm{~cm}^{-1}$ correspond with the presence of $\mathrm{H}_{2} \mathrm{O}$. The main difference of FTIR spectra between fish bone powder and hydroxyapatite lies on peaks at 2840 and $2910 \mathrm{~cm}^{-1}$ also supported by $1600 \mathrm{~cm}^{-1}$ which represents $\mathrm{N}-\mathrm{H}$ absorption band of protein contained in the fish bone powder. 
The surface area of hydroxyapatite is measured based on nitrogen desorption adsorption isotherms. Figure 3 shows the type of hydroxyapatite isotherm properties following type IV and H3 hysteresis loop type. The hydroxyapatite has a BET surface area of 138.20 $\mathrm{m}^{2} / \mathrm{g}$, while total pore volume and average pore diameter of hydroxyapatite were obtained 0.257 $\mathrm{cm}^{3} / \mathrm{g}$ and $8.91 \mathrm{~nm}$, respectively. The surface area of hydroxyapatite in this study had large than the commercial hydroxyapatite, which is $36.7 \mathrm{~m}^{2} / \mathrm{g} 34$.

\subsection{Adsorption study}

Interaction mechanism between $\mathrm{Ni}(\mathrm{II})$ with hydroxyapatite occurs in several ways. One of the possible mechanisms is through ion exchange. Calcium ions within hydroxyapatite were replaced by $\mathrm{Ni}$ (II) from solution. The adsorption process proceeds in 2 steps. The first step, Ni(II) rapidly adsorbed onto hydroxyapatite surface particularly at the $\mathrm{POH}$ groups a forms $\mathrm{Ca}_{10-\mathrm{x}} \mathrm{M}_{\mathrm{x}}\left(\mathrm{PO}_{4}\right)_{6}(\mathrm{OH})_{2}$, the next step is substitution of $\mathrm{Ca}^{2+}$ by $\mathrm{Ni}^{2+}$, according to reaction 21,39:

$$
\mathrm{Ca}_{10}\left(\mathrm{PO}_{4}\right)_{6}(\mathrm{OH})_{2}+\mathrm{xM}^{2+} \rightarrow \mathrm{Ca}_{10-\mathrm{x}} \mathrm{M}_{\mathrm{x}}\left(\mathrm{PO}_{4}\right)_{6}(\mathrm{OH})_{2}+\mathrm{xCa}^{2+}
$$

Another possible mechanism is through electrostatic attraction between hydroxyapatite and $\mathrm{Ni}$ (II). The solution $\mathrm{pH}$ influences the electrostatic attraction between hydroxyapatite and Ni(II). The pHpzc (Point zero charge) was determined using the $\mathrm{pH}$ drift method. The intersection between $\mathrm{pH}$ first and $\mathrm{pH}$ final is the $\mathrm{pH}_{\mathrm{PZC}}$. The $\mathrm{pH}_{\mathrm{PZC}}$ of hydroxyapatite at 6.4 depicted in Figure 4. At solution $\mathrm{pH}<\mathrm{pH}_{\mathrm{PZC}}$, the surface of hydroxyapatite is positively charged whereas, above the $\mathrm{pH}_{\mathrm{PZC}}$, the surface of hydroxyapatite became negatively charged.

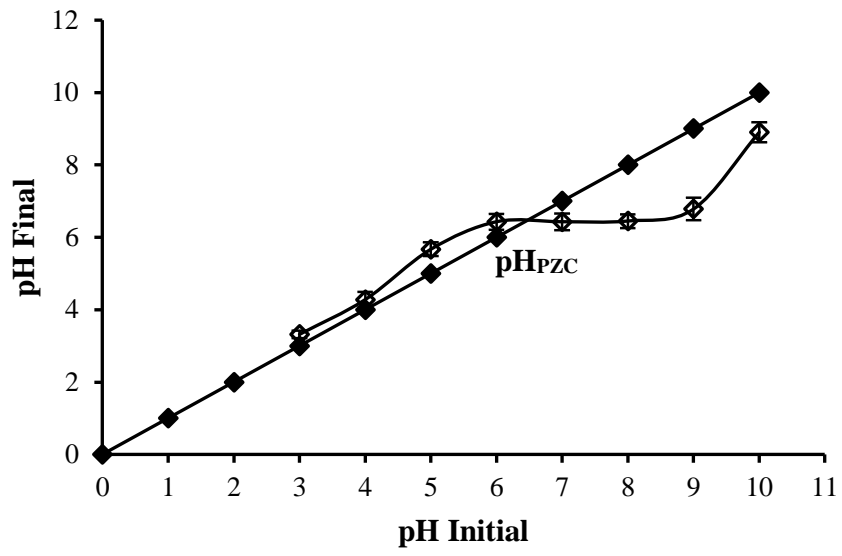

Figure 4. $\mathrm{pH}_{\mathrm{PZC}}$ of hydroxyapatite
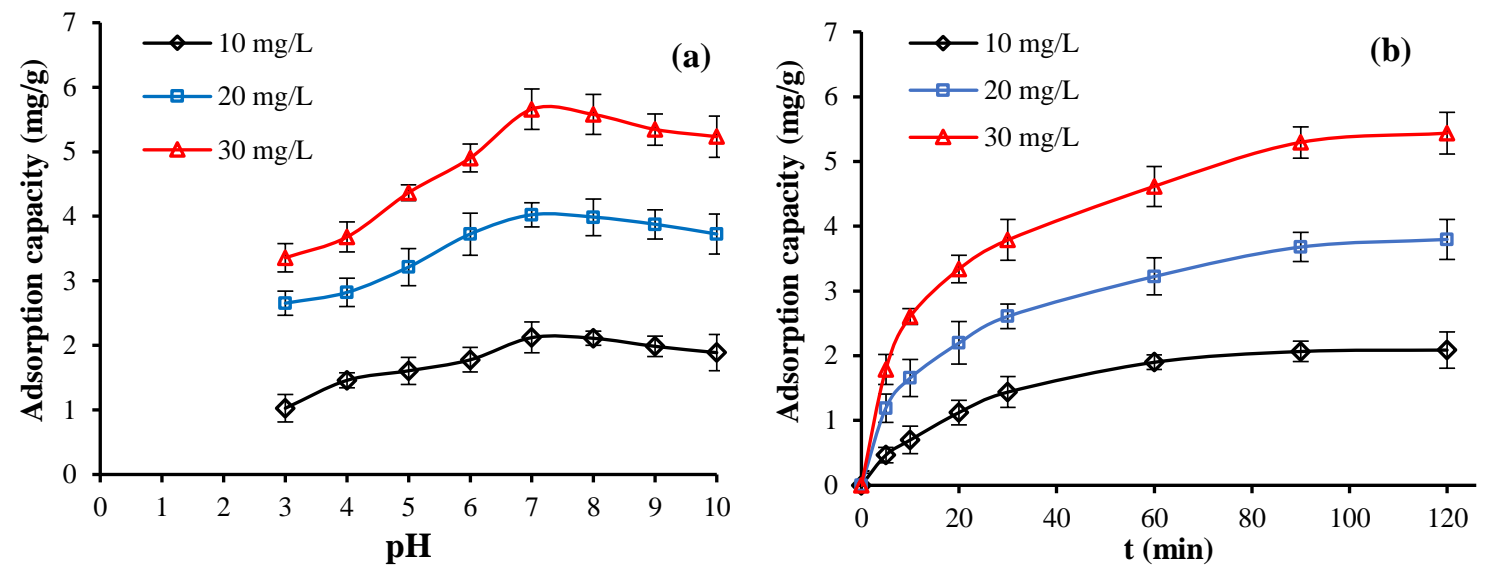

Figure 5. Sorption of $\mathrm{Ni}(\mathrm{II})$ by hydroxyapatite at (a) various $\mathrm{pH}$ and (b) contact time

Figure 5a confirmed that interaction is more effective above $\mathrm{pH}_{\mathrm{PZC}}$. Range of $\mathrm{pH}$ used in this work was 310. Adsorption capacity increased at $\mathrm{pH} 3$ through $\mathrm{pH}$ 7. At low $\mathrm{pH}, \mathrm{Ni}^{2+}$ and $\mathrm{H}^{+}$are positively charged, while hydroxyapatite is also positively charged, so there is an electrostatic repulsion. Increasing the $\mathrm{pH}$ of the solution so reducing $\mathrm{H}^{+}$in the solution ${ }^{40}$. If the $\mathrm{pH}$ of the solution $>\mathrm{pH}_{\mathrm{PZC}}, \mathrm{H}^{+}$become less available so that more $\mathrm{Ni}^{2+}$ is being adsorbed. Optimum $\mathrm{pH}$ for the adsorption process obtained in this work is 7 at all variation of $\mathrm{Ni}(\mathrm{II})$ concentrations. At this $\mathrm{pH}$, hydroxyapatite is negatively charged, which attracts positively charge $\mathrm{Ni}^{2+}$ and raised its capacity. This is a common phenomenon in metal ions adsorption ${ }^{41}$. The optimum $\mathrm{pH}$ for $\mathrm{Ni}(\mathrm{II})$ adsorption reported by several authors at range 6-8 4,10,41. At $\mathrm{pH} 8$, the adsorption capacity decreases. $\mathrm{Ni}$ (II) in the solution tends to precipitate to $\mathrm{Ni}(\mathrm{OH})_{2}{ }^{10,42}$. 
The effect of contact time against adsorption capacity of hydroxyapatite is illustrated in Figure $5 \mathrm{~b}$. The experiment was conducted at 3 different initial concentration of $\mathrm{Ni}$ (II) i.e. 10,20 and $30 \mathrm{mg} / \mathrm{L}$, the weight of hydroxyapatite $0.1 \mathrm{~g}$, the contact time was varied from 0 to 120 minutes, stirring at $120 \mathrm{rpm}$ and room temperature. These 2 steps of the adsorption process, initially $\mathrm{Ni}(\mathrm{II})$ is adsorbed rapidly until it reaches equilibrium i.e. the outer surface of hydroxyapatite becomes saturated. In this study, reached the equilibrium was obtained at 90 minutes. The second adsorption process occurred through the infiltration of $\mathrm{Ni}$ (II) into the inner surface of the adsorbent ${ }^{21,40}$. Adsorption duration effect at this stage is negligible because it happened indefinitely in time.

\subsection{Adsorption kinetics}

Mechanism of adsorption $\mathrm{Ni}(\mathrm{II})$ on hydroxyapatite was investigated through adsorption kinetic. Two models were presented i.e. pseudo-first-order and pseudo-second-order. The pseudo-first-order provides the most straightforward approach to describe solute adsorbed on the adsorbent; it is formulated as follows:

$\log \left(q_{e}-q_{t}\right)=\log q_{t}-\frac{k_{1}}{2.303} t$

$q_{e}$ and $q_{t}(\mathrm{mg} / \mathrm{g})$ represent $\mathrm{Ni}(\mathrm{II})$ adsorbed at equilibrium and at $\mathrm{t}$ time respectively. $k_{1}$ is equilibrium constant for pseudo-first-order (1/min). The constant was obtained by plotting $\log \left(q_{e}-q_{t}\right)$ Versus $t$. Pseudo-second orde, on the other hand, presumed that adsorption occurs in chemisorption type ${ }^{39}$. The linear equation for this approach is formulated:

$\frac{t}{q_{e}}=\frac{1}{k_{2} q_{e}^{2}}+\frac{t}{q_{e}}$

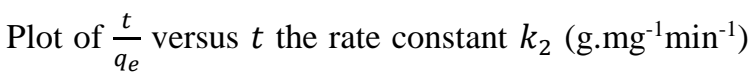
can be determined. Figure 6 displays pseudo-firstorder and pseudo-second-order plots, while Table 1 shows the kinetic parameter of $\mathrm{Ni}$ (II) with a concentration of $\mathrm{Ni}(\mathrm{II})$ is 10,20 and $30 \mathrm{mg} / \mathrm{L}$.

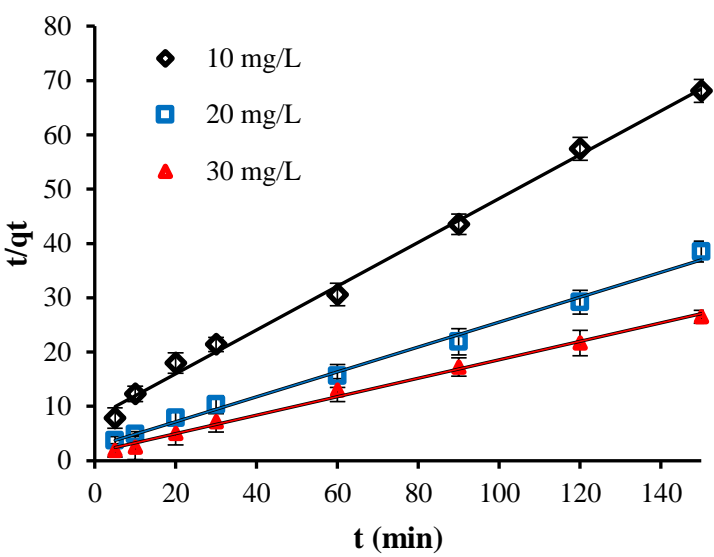

Figure 6. (a) Pseudo-first order dan (b) Pseudo-second order of Ni(II) sorption by hydroxyapatite

Table 1. The Kinetic parameters pseudo-first order and pseudo-second order.

\begin{tabular}{|c|c|c|c|c|c|c|c|}
\hline \multirow{2}{*}{$\begin{array}{c}\text { Ni (II) } \\
(\mathbf{m g} / \mathrm{L})\end{array}$} & \multirow{2}{*}{$\begin{array}{l}q_{\boldsymbol{e}}(\mathbf{m g} / \mathbf{g}) \\
\text { Eksp. }\end{array}$} & \multicolumn{3}{|c|}{ Pseudo-first order } & \multicolumn{3}{c|}{ Pseudo-second order } \\
\cline { 3 - 8 } & & $\begin{array}{c}q_{e}(\mathrm{mg} / \mathrm{g}) \\
\text { calculation }\end{array}$ & $k_{1}(1 / \mathrm{min})$ & $R^{2}$ & $q_{e}(\mathrm{mg} / \mathrm{g})$ & $k_{2}$ & $R^{2}$ \\
calculation & (g/mg.min) & \\
\hline $\mathbf{1 0}$ & 1.920 & 1.024 & 0.035 & 0.9924 & 2.481 & 0.0201 & 0.9956 \\
\hline $\mathbf{2 0}$ & 3.811 & 1.026 & 0.025 & 0.9925 & 4.369 & 0.0200 & 0.9939 \\
\hline $\mathbf{3 0}$ & 6.486 & 1.036 & 0.023 & 0.9933 & 5.886 & 0.0186 & 0.9946 \\
\hline
\end{tabular}

Table 1 confirmed at increase $\mathrm{Ni}(\mathrm{II})$ concentration, the number of adsorbed ions also increase both experimentally and theoretically while the rate constants $\left(k_{1}\right.$ dan $\left.k_{2}\right)$ tend to decrease. At a higher amount of $\mathrm{Ni}$ (II) adsorption, the surface of hydroxyapatite becomes saturated so that the rate will decrease. The coefficient of $R^{2}$ obtained for pseudosecond-order for all initial concentration of $\mathrm{Ni}$ (II) is higher than pseudo-first-order, indicated that adsorption of $\mathrm{Ni}$ (II) best fit to pseudo-second-order. Based on the result, it is likely that the adsorption process follows multistep chemisorption type ${ }^{2}$. A similar result has been reported in $\mathrm{Ni}(\mathrm{II})$ adsorption using activated carbon ${ }^{6}$, moringa oleifera ${ }^{10}$ and clay $^{39}$.

\subsection{Adsorption thermodynamic}

Thermodynamic of $\mathrm{Ni}$ (II) adsorption on hydroxyapatite was evaluated based on the value of Gibbs standard energy $\left(\Delta G^{o}\right)$, standard enthalpy $\left(\Delta H^{o}\right)$, and standard entropy $\left(\Delta \mathrm{S}^{\circ}\right)$. The values of these three parameters can be determined by using the equation:

$$
\begin{aligned}
& \Delta G^{o}=-R T \ln K \\
& \Delta G^{o}=\Delta H^{o}-T \Delta S^{o}
\end{aligned}
$$


$\ln K=\frac{\Delta S^{o}}{R}-\frac{\Delta H^{o}}{R T}$

$K(\mathrm{~L} / \mathrm{g})$ is equilibrium constant, $R$ is ideal gas constant (8.314.10-3 $\mathrm{KJ} / \mathrm{mol} . \mathrm{K})$, and $\mathrm{T}$ is temperature $(\mathrm{K})$. Figure 7 illustrates the plot of $\ln K$ versus $1 / \mathrm{T}$ giving $R^{2}$ value of $0.9882 . \Delta H^{o}$ and $\Delta S^{o}$ were obtained from the slope and intercept; the overall calculation result is shown in Table 2. $\Delta G^{o}$ was found out negative at all temperature which concludes that adsorption occurs spontaneously. The value of $\Delta G^{o}$ decrease as temperature increase suggests the presence of electrostatic attraction results in an increase of adsorption capacity. Moreover, it reflects a favorable condition for the reaction at a higher temperature ${ }^{10}$. $\Delta H^{o}$ shows value for the endothermic process of adsorption whereas positive $\Delta S^{o}$ express the increase of hydroxyapatite affinity happened in random during adsorption of $\mathrm{Ni}(\mathrm{II})$.

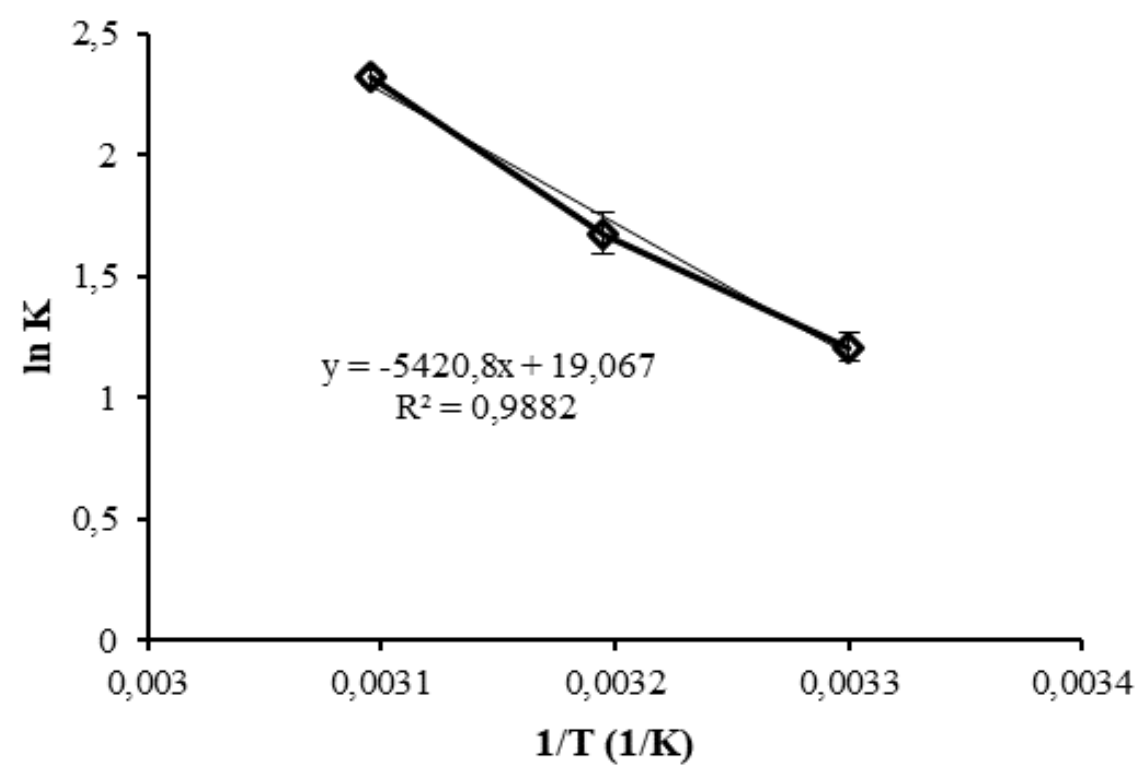

Figure 7. Plot of $\ln \mathrm{K}$ Vs $1 / \mathrm{T}$ of $\mathrm{Ni}(\mathrm{II})$ sorption by hydroxyapatite

Table 2. Thermodynamic parameters of Ni(II) sorption by hydroxyapatite.

\begin{tabular}{|c|c|c|c|c|}
\hline $\mathbf{T}(\mathbf{K})$ & $-\Delta \boldsymbol{G}^{\boldsymbol{o}}(\mathbf{K J} / \mathbf{m o l})$ & $\Delta \boldsymbol{S}^{\boldsymbol{o}}(\mathbf{J} / \mathbf{m o l} . \mathbf{K})$ & $\Delta \boldsymbol{H}^{\boldsymbol{o}}(\mathbf{K J} / \mathbf{m o l})$ & $\boldsymbol{R}^{\mathbf{2}}$ \\
\hline $\mathbf{3 0 3}$ & 3.048 & & & \\
\hline $\mathbf{3 1 3}$ & 4.366 & 0.158 & 45.068 & 0.9882 \\
\hline $\mathbf{3 2 3}$ & 6.230 & & & \\
\hline
\end{tabular}

\subsection{Adsorption Isotherm}

The adsorption system design can be examined from adsorption isotherm ${ }^{2}$. Two adsorption isotherms were used in this work i.e. Langmuir and Freundlich. Langmuir isotherm assumed the adsorbent surface is homogeneous and each active site can absorb one molecule to form monolayer ${ }^{21,43}$. The Langmuir isotherm is as a follow:

$\frac{C_{e}}{q_{e}}=\frac{C_{e}}{q_{m}}+\frac{1}{q_{m}} K_{L}$

The concentration of $\mathrm{Ni}(\mathrm{II})$ at equilibrium denoted by $C_{e}(\mathrm{mg} / \mathrm{L})$, number of $\mathrm{Ni}(\mathrm{II})$ adsorbed per unit weight at equilibrium denoted by $q_{e}(\mathrm{mg} / \mathrm{g})$ and a maximum capacity of $\mathrm{Ni}$ (II) adsorbed express by $q_{m}$ (mg/g). Constant related to adsorption energy is written as $K_{L}$ $(1 / \mathrm{mg})$ which can be obtained from the plot $\frac{C_{e}}{q_{e}}$ versus $C_{e}$. Other than, Freundlich isotherm assumed heterogeneous system on hydroxyapatite.
Mathematical expression for Freundlich isotherm is written as:

$\ln q_{e}=\ln K_{F}+\frac{1}{n} \ln C_{e}$

$q_{e}(\mathrm{mg} / \mathrm{g})$ represent the number of $\mathrm{Ni}(\mathrm{II})$ ion adsorbed per gram, $K_{F}$ is Freundlich constant $(\mathrm{mg} / \mathrm{g})$ and the empirical constant is expressed as $n$, if $n<1$, is unfavourable process, and $0<n<1$ is favourable process. Table 3 shows calculated adsorption isotherm parameters according to Langmuir and Freundlich models at room temperature. The Langmuir isotherm provides $R^{2}$ greater than Freundlich. So, the adsorption of $\mathrm{Ni}(\mathrm{II})$ to hydroxyapatite in accordance with the Langmuir model. The adsorption capacity of hydroxyapatite is obtained $5.359 \mathrm{mg} / \mathrm{g}$. Freundlich parameter show $n>1$, which implies a favorable adsorption process ${ }^{44}$. 
Table 3. Adsorption isotherm parameters of Ni(II) sorption onto hydroxyapatite.

\begin{tabular}{|c|c|c|c|}
\hline \multicolumn{2}{|c|}{ Langmuir } & \multicolumn{2}{c|}{ Freundlich } \\
\hline $\boldsymbol{q}_{\boldsymbol{m}}(\mathbf{m g} / \mathbf{g})$ & 5.359 & $K_{F}(\mathrm{mg} / \mathrm{g})$ & 1.601 \\
\hline $\boldsymbol{K}_{\boldsymbol{L}}(\mathbf{L} / \mathbf{m g})$ & 0.0273 & $n(\mathrm{~g} / \mathrm{L})$ & 3.617 \\
\hline $\boldsymbol{R}^{\mathbf{2}}$ & 0.9916 & $R^{2}$ & 0.9422 \\
\hline
\end{tabular}

\subsection{Morphology and elements of hydroxyapatite before and after $\mathrm{Ni}$ (II) sorption}

Figure 8 depicted the hydroxyapatite morphology recorded by SEM. Hydroxyapatite has an irregular spherical shape, porous surface in an open pore mode. Agglomeration of hydroxyapatite appears as a consequence of nanosized material. Similar morphology has been reported by several authors who prepared hydroxyapatite with combustion method 29 and sol-gel methods ${ }^{45}$ to obtain agglomerate and porous material. EDS hydroxyapatite data before and

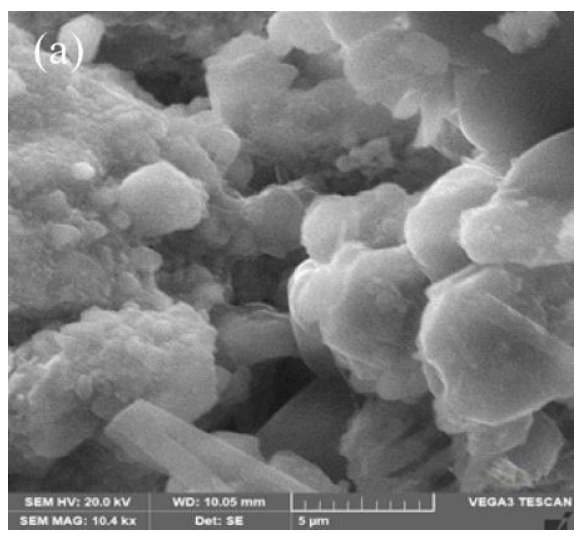

after adsorption is shown in Table 4. Hydroxyapatite consists of elements including $\mathrm{O}, \mathrm{Ca}$ dan $\mathrm{P}$, and after adsorption process, there is the addition of $\mathrm{Ni}$. The elements of hydroxyapatite before adsorption had of $\mathrm{O}, \mathrm{Ca}$ and $\mathrm{P}$ of $51.90,33.04$ dan $15.06 \%$. The molar ratio $(\mathrm{Ca} / \mathrm{P})$ of hydroxyapatite is 1.70 approaching the theoretical 1.67. These results indicate that synthesized product has high purity. The composition of the elements after adsorption consisted of $\mathrm{O}, \mathrm{Ca}, \mathrm{P}$, and $\mathrm{Ni}$ which each had values of 40.44, 35.49, 16.08, and $7.99 \%$, respectively.

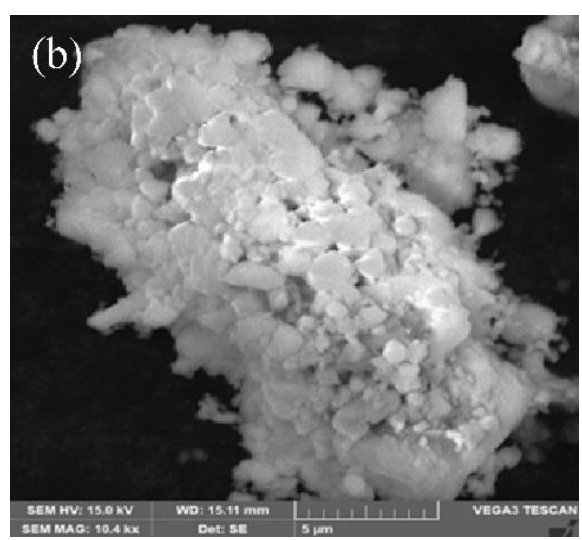

Figure 8. Morphology of hydroxyapatite (a) before and (b) after Ni(II) sorption

Table 4. Elements of hydroxyapatite before and after Ni(II) sorption.

\begin{tabular}{|l|c|c|}
\hline \multirow{2}{*}{ Elements } & \multicolumn{2}{|c|}{ Hydroxyapatite } \\
\cline { 2 - 3 } & Before adsorption (\%) & After adsorption (\%) \\
\hline $\mathbf{O}$ & 51.90 & 40.44 \\
\hline $\mathbf{P}$ & 33.04 & 35.49 \\
\hline $\mathbf{N i}$ & 15.06 & 16.08 \\
\hline
\end{tabular}

Table 5 shows the adsorption capacity of various adsorbents used in the reported removal of $\mathrm{Ni}(\mathrm{II})$ compared to this work. Many natural-based adsorbents have been developed recently. The main reason is economical and environmentally friendly. It seems that our results still have a low adsorption capacity compared to the others, but it shows high potential, especially in the elimination of $\mathrm{Ni}(\mathrm{II})$.

Table 5. Adsorption capacity comparison between various adsorbent for Ni(II) removal.

\begin{tabular}{|l|c|c|}
\hline \multicolumn{1}{|c|}{ Adsorbent } & Adsorption capacity (mg/g) & References \\
\hline Clinoptilolite & 5.08 & 46 \\
\hline Amine-functionalized modified rice straw & 3.95 & 47 \\
\hline Granular activated carbon & 1.49 & 48 \\
\hline Cucumis melo peel-activated carbon & 5.43 & 49 \\
\hline Sewage sludge & 11.52 & 50 \\
\hline Chitosan/diatomaceous earth composite & 149.64 & 42 \\
\hline Spent coffee & 57.14 & 51 \\
\hline Coffee husk & 51.91 & 51 \\
\hline Hydroxyapatite & 5.359 & In this study \\
\hline
\end{tabular}




\section{Conclusion}

In this study, hydroxyapatite synthesized from snakehead fish bone by precipitation method has been successful. Hydroxyapatite was an effective biosorbent for removal $\mathrm{Ni}$ (II) from solution. Utilization of hydroxyapatite for $\mathrm{Ni}(\mathrm{II})$ adsorption was influenced by the $\mathrm{pH}$ of the solution, $\mathrm{Ni}(\mathrm{II})$ concentration and contact time. Finally, the adsorption of $\mathrm{Ni}$ (II) by hydroxyapatite follows pseudo-second-order kinetic approach and best described by Langmuir isotherm model with an adsorption capacity of $5.359 \mathrm{mg} / \mathrm{g}$. Thermodynamic quantities concluded that adsorption occurs spontaneously and endothermically. Hydroxyapatite prepared from snakehead fish bone shows the potential for adsorption of $\mathrm{Ni}$ (II) from wastewater.

\section{Acknowledgements}

The author would like to thank for funding for Kementerian Riset Teknologi dan Pendidikan Tinggi Republik Indonesia Hibah Penelitian Dasar Unggulan Perguruan Tinggi (PDUPT) grants and Department of Chemistry, Sriwijaya University for research facilities.

\section{References}

1- S. L. Iconaru, M. M. Heino, R. Guegan, M. V. Predoi, A. M. Prodan, D. Predoi, Removal of zinc ions using hydroxyapatite and study of ultrasound behavior of aqueous media, Materials, 2018, 11(1350), 1-16.

2- M. Mohammad, S. Maitra, N. Ahmad, A. Bustam, T. K. Sen, B. K. Dutta, Metal ion removal from aqueous solution using physic seed hull, J Hazard. Mater., 2010, 179(1-3), 363-372.

3- P. K. Pandey, S. Choubey, Y. Verma, M. Pandey, S. S. K. Kamal, K. Chandrashekhar, Biosorptive removal of $\mathrm{Ni}$ (II) from wastewater and industrial effluent, Int. J. Environ. Res. Public Health, 2007, 4(4), 332-339.

4- X. Zhang, X. Wang, Adsorption and desorption of nickel (II) ions from aqueous solution by a lignocellulose/montmorillonite nanocomposite, Plos One, 2015, 3, 1-21.

5- M. A. Khan, M. Ngabura, T. S. Y. Choong, H. Masood, L. A. Chuah, Biosorption and desorption of nickel on oil cake: batch and column studies, Bioresour Technol., 2012, 103(1), 35-43.

6- K. Kadirvelu, K. Thamaraiselvi, C. Namasivayam, Adsorption of nickel (II) from aqueous solution onto activated carbon prepared from coir pith, Sep Puri Technol., 2001, 24(3), 497-505.

7- K. Allam, A. El Bouari, B. Belhorma, and L. Bih, Removal of Methylene Blue from Water Using Hydroxyapatite Submitted to Microwave Irradiation, J Water Resource Prot., 2016, 8(3), 358-371.
8- G. Ciobanu, S. Barna, M. Harja, Kinetic and equilibrium studies on adsorption of Reactive Blue 19 dye from aqueous solutions by nanohydroxyapatite adsorbent, Arch. Environ. Prot., 2016, 42(2), 3-11.

9- N. A. M. Barakat, M. S. Khil, A. M. Omran, F. A. Sheikh, H. Y. Kim, Extraction of pure natural hydroxyapatite from the bovine bones biowaste by three different methods, J. Mater. Process. Technol., 2009, 209(7), 3408-3415.

10-H. K. Reddy, D. K.V. Ramana, K. Seshaiah, A. V. R. Reddy, Biosorption of Ni(II) from aqueous phase by Moringa Oleifera bark, a lowcost biosorbent, Desalination, 2017, 268 (1-3), 150-157.

11-N. Singh, and R. Gadi, Removal of Ni(II) and $\mathrm{Cu}$ (II) from their solutions and wastewater by nonliving biomass of Pseudomonas Oleovorans, Hydrol Current Res., 2012, 3(1), 1-4.

12-M. Boutinguiza, J. Pou, R. Comesana, F. Lusquifios, A. de Carlos, B. Leon, Biological hydroxyapatite obtained from fish bone, Mater Sci Eng C, 2012, 32(3), 478-486.

13-H. Zhou, J. Lee, Nanoscale hydroxyapatite particles for bone tissue engineering, Acta Biomater, 2011, 7(7), 2769-2781.

14-S. M. Mousa, N. S. Ammar, H. A. Ibrahim, Removal of lead ions using hydroxyapatite nanomaterial prepared from phosphogypsum waste, $\mathrm{J}$ Saudi Chem Soc., 2016, 20(3), 357-365.

15-S. C. Wu, H. C. Hsu, S. K. Shu, Y. C. Chang, Wen. F. Ho, Synthesis of hydroxyapatite from eggshell powders through ball milling and heat treatment, J Asian Ceram Soc., 2016, 4(1), 85-90.

16-P. Joshi, S. Manocha, Kinetic and thermodynamic study of the adsorption of copper ions on hydroxyapatite nanoparticles, Mater Today, 2017, 4(9), 10455-10459.

17-S. George, D. Mehta, V. K. Saharan, Application of hydroxyapatite and its modified forms as adsorbents for water defluoridation: an insight into process synthesis, Rev Chem Eng., 2018, 1-32.

18-Y. Nishiyama, T. Hanafusa, J. Yamashita, Y. Yamamoto, T. Ono, Adsorption and removal of strontium in aqueous solution by synthetic hydroxyapatite, J Radioanal Nucl Chem., 2016, 307(2), 1279-1285.

19-M. Harja, G. Ciobanu, Removal of oxytetracycline from aqueous solutions by hydroxyapatite as a low-cost adsorbent, in International Conference on Advances in Energy Systems and Environmental Engineering (ASEE17), Poland, July 2-5, 2017, 1-8.

20-Y. Song, J. Gao, Y. Zhang, S. Song, Preparation and characterization of nano-hydroxyapatite and its competitive adsorption kinetics of copper and lead ions in water, Nanomater Nanotechno., 2016, 6(1-8), 1-8.

21-S. M. H. Dabiri, A. A. Rezaie, M. Moghimi, 
H. Rezaie, Extraction of Hydroxyapatite from Fish Bones and Its Application in Nickel Adsorption, BioNanoScience, 2018, 8(3), 823-834.

22-M. Mourabet, A. El Rhilassi, H. El. Boujaady, M. B. Ziatni, R. El. Hamri, A. T. Tai, Removal of fluoride from aqueous solution by adsorption on hydroxyapatite (HAp) using response surface methodology, J Saudi Chem Soc, 2015, 19(6), 603-615.

23-B. R. Sunil, M. Jagannatham, Producing hydroxyapatite from fish bones by heat treatment, Mater Lett., 2016, 185, 411-414.

24-S. Rujitanapanicha, P. Kumpapanb, P. Wanjanoic, Synthesis of Hydroxyapatite from Oyster Shell via Precipitation, Energy Procedia, 2014, 56, 112-117.

25-M. F. Alif, W. Aprillia, S. Arief, Peat water purification by hydroxyapatite (HAp) synthesized from waste pensi (Corbicula moltkiana) shells, in International Conference on Chemistry and Material Science (IC2MS), Malang Indonesia, 4-5 November 2017, pp. 1-6.

26-R. N. Granito, A. C. M. Renno, H. Yamamura, M. C. de Almeida, P. L. M. Ruiz, D. A. Ribeiro, "Hydroxyapatite from fish for bone tissue engineering: A Promising Approach, Int. J. Mol. Cell. Med. Spring, 2018, 7(2), 80-90.

27-K. Allam, A. El Bouari, B. Belhorma, L. Bih, Removal of methylene blue from water using hydroxyapatite submitted to microwave irradiation, J Water Resource Prot., 2016, 8, 358-371.

28-B. A. E. Ben-Arfa, I. M. M. Salvado, J. M. F. Ferreira, Nouvel route for the rapid sol-gel synthesis of hydroxyapatite, avoiding ageing and using fast drying with a 50-fold to 200-fold reducting in process time, Mater Sci Eng C Mater Biol Appl., 2017, 70(1), 796-804.

29-M. Canillas, R. Rivero, R. G. Carrodeguas, F. Barba, M. A. Rodriguez, Processing of hydroxyapatite obtained by combustion synthesis, Bol Soc Esp Ceram V, 2017, 56(5), 237-242.

30-W. Kim, F. Saito, Sonochemical synthesis of hydroxyapatite from $\mathrm{H}_{3} \mathrm{PO}_{4}$ solution with $\mathrm{Ca}(\mathrm{OH})_{2}$, Ultrason Sonochem., 2001, 8(2), 85-88.

31-I. Mobasherpour, M. S. Heshajin, A. Kazemzadeh, M. Zakeri, Synthesis of nanocrystalline hydroxyapatite by using precipitation method, J Alloys Compd., 2007, 430(1-2), 330-333.

32-M. Okada, T. Matsumoto, Synthesis and modification of apatite nanoparticles for use in dental and medical applications, Jpn Den Sci Rev., 2015, 51(4), 85-95.

33-W. Wei, L. Yang, W. Zhong, J. Cui, Z. Wei, Poorly crystalline hydroxyapatite: A novel adsorbent for enhanced fulvic acid removal from aqueous solution, 2015, Appl Surf Sci., 332, 328-339.
34- A. R. Ibrahim, Y. Zhou, X. Li, L. Chen, Y. Hong, Y. Su, H. Wang, J. Li, Synthesis of rod-like hydroxyapatite with high surface area and pore volume from eggshells for effective adsorption of aqueous $\mathrm{Pb}(\mathrm{II})$, Mater Res Bull., 2015, 62, 132-141.

35-M. S. Shojai, M. T. Khorasani, E. D. Khoshdargi, A. Jamshidi, Synthesis methods for nano size hydroxyapatite in diverse structures, Acta Mater., 2013, 9(8), 7591-7621.

36- A. Pal, S. Paul, A. R. Choudhury, V. K. Balla, M. Das, and A. Sinha, Synthesis of hydroxyapatite from Lates calcarifer fish bone for biomedical applications, Mater Lett., 2017, 203, 89-92.

37-P. Wang, C. Li, H. Gong, X. Jiang, H. Wang, $\mathrm{K}$. Li, Effect of synthesis conditions on the morphology of hydroxyapatite nanoparticles produced by a wet chemical process, Powder Technol., 2010, 2013(2), 315-321.

38-P. Kamalanathan, S. Ramesh, L. T. Banga, A. Niakan, C.Y. Tan, J. Purbolaksono, H. Chandran, W. D. Teng, Synthesis and sintering of hydroxyapatite derived from eggshells as a calcium precursor, Ceram Int., 2014, 40(10), 16349-16359.

39-S. S. Gupta, K. G. Bhattacharya, Adsorption of $\mathrm{Ni}(\mathrm{II})$ on clays, J Colloid Interface Sci., 2016, 295(1), 21-32.

40-S. S. Salih, T. K. Ghosh, Preparation and characterization of bioadsorbent beads for chromium and zink ion adsorption, Cogent Environ Sci., 2017, 3, 1-14.

41-I. Mobasherpour, E. Salahi, M. Pazouki, Comparative of the removal of $\mathrm{Pb}^{2+}, \mathrm{Cd}^{2+}$ and $\mathrm{Ni}^{2+}$ by nano crystallite hydroxyapatite from aqueous solutions: Adsorption isotherm study, Arab J Chem., 2012, 5(4), 439-446.

42-S. S. Salih, T. K. Ghosh, Highly efficient competitive removal of $\mathrm{Pb}$ (II) and $\mathrm{Ni}$ (II) by chitosan/diatomaceous earth composite, J Environ Chem Eng., 2018, 6(1), 435-443.

43-S. S. Salih, T.K. Ghosh, Preparation and characterization of chitosan-coated diatomaceous earth for hexavalent chromium removal, Environ. Process, 2018, 5, 23-39.

44- A. I. Adeogun, E. A. Ofudje, M. A. Idowu, S. O. Kareem, S. Vahidhabanu, B. R. Babu, Biowastederived hydroxyapatite for effective removal of reactive yellow 4 dye: equilibrium, kinetic, and thermodynamic studies, ACS Omega, 2018, 3(2), 1991-2000.

45-I. Kim, P. N. Kumta, Sol-gel synthesis and characterization of nanostructured hydroxyapatite powder, Mater Sci Eng B., 2004, 111(2-3), 232-236.

46-O. Oter, H. Akcay, Use of natural clinoptilolite to improve water quality: sorption and selectivity studies of lead (II), copper (II), zinc( II), and nickel (II), Water Environ Res., 2007, 79(3), 329-335. 
47-W. Yunhai, F. Yiang, Z. Meili, M. Zhu, Y. Shengxin, A. Aynigar, F. Peng,

Functionalized agricultural biomass as a low-cost adsorbent: Utilization of rice straw incorporated with amine groups for the adsorption of $\mathrm{Cr}(\mathrm{VI})$ and $\mathrm{Ni}$ (II) from single and binary systems, Biochem Eng J., 2016; 105, 27-35.

48-K. Periasamy, C. Namasivayam, Removal of nickel(II) from aqueous solution and nickel plating industry using agricultural waste: peanut hulls, Waste Manage., 1995, 15(1), 63-68.

49-M. Manjuladevi, R. Anitha R. and S. Manonmani, Kinetic study on adsorption of $\mathrm{Cr}(\mathrm{VI}), \mathrm{Ni}(\mathrm{II}), \mathrm{Cd}(\mathrm{II})$ and $\mathrm{Pb}(\mathrm{II})$ ions from aqueous solutions using activated carbon prepared from Cucumis melo peel, Appl Water Sci., 2018, 8(36), 1-8.
50-O. Khelifi, M. Nacef, A. M. Affoune, Nickel (II) Adsorption from Aqueous Solutions by PhysicoChemically Modified Sewage Sludge, Iran J Chem Eng., 2018; 37: 73-87.

51-M. H. Rodiguez, J. Yperman, R. Carleer, J. Maggen, D. Dadi, G. Gryglewicz, B. V. der Bruggen, J. F. Hernandez, A. O. Calvis, Adsorption of $\mathrm{Ni}$ (II) on spent coffee and coffee husk based activated carbon, J Environ Chem Eng, 2018, 6(1), 1161-1170. 